\title{
Metadiscourse Analysis of Pakistani English Newspaper Editorials: A Corpus-Based Study
}

\author{
Ali Raza Siddique ${ }^{1}$, Muhammad Asim Mahmood ${ }^{1} \&$ Javed Iqbal $^{2}$ \\ ${ }^{1}$ Department of Applied Linguistics, Government College University Faisalabad, Pakistan \\ ${ }^{2}$ University of Gujrat, Gujrat, Pakistan \\ Correspondence: Ali Raza Siddique, Department of Applied Linguistics, Government College University, \\ Faisalabad, Punjab, Pakistan. E-mail: Aalimalik381@gmail.com
}

Received: June 13, 2017 Accepted: August 26, 2017 Online Published: October 25, 2017

doi:10.5539/ijel.v8n1p146

URL: https://doi.org/10.5539/ijel.v8n1p146

\begin{abstract}
Metadiscourse markers (MMs) are lexical resources that writers use to organize their discourse and express their stance about the content or the reader. Metadiscourse analysis of Pakistani English Newspaper Editorials (PENE) has been conducted. The corpus of this study has contained 1000 editorials taken from four renowned Pakistani newspapers: Dawn News (DN), The Frontier (TF), The Express Tribune (TET) and The News (TN). The distribution of 250 editorials from each newspaper has been retrieved from online sources. The frequencies of metadiscourse features (MFs) have been counted and compared, and further studied metadiscourse features (MFs) functionally on the basis of propositional and non-propositional contents. A comprehensive model on Interpersonal metadiscourse has been proposed and it has been categorized into interactive and interactional markers. A comprehensive scheme of metadiscourse markers (MMs) has been proposed for the analysis of the present study. The findings revealed that all corpora used more interactive than interactional markers. In this regard, the sub-categories of interactive metadiscourse such as sequencing markers and transition markers have been frequently observed in the corpus of The Frontier (TF) as compared to other said corpora. The sub-categories of interactional metadiscourse such as engagement, and hedges have been frequently seen in the corpus of The Frontier (TF) as compared to other said corpora. In conclusion, this study has claimed that The Frontier (TF) is more reader-friendly because of the excessive use of interactive metadiscourse.
\end{abstract}

Keywords: interpersonal, interactive metadiscourse, interactional metadiscourse, Pakistani English Newspapers Editorials (PENE)

\section{Introduction}

The linguistic term Metadiscourse plays an important role in order to construct and develop not only persuasive writing but also meaningful writing. The use of metadiscourse in writing is perceived as an intentional act of the writer. Metadiscourse study is very crucial in learning English writing. It is unfortunate situation pertaining to Pakistani learners who are immature in the usage of MMs appropriately in their writings.

Keeping in mind, the focus of this study is mainly emphasizing the study of MFs in PENE. The present study deals interpersonal metadiscourse which is categorized into interactive and interactional categories. This study shares an advancement in analysis of metadiscourse of PENE. For the present study, a corpus of 1000 editorials has been retrieved manually from online source. The distribution of 250 editorials from each newspaper has been devised to the following newspapers (i.e., DN, TET, TE, and TN). The developed corpus has been used for metadiscourse analysis in PENE.

For this study, the researcher has proposed a new interpersonal model on metadiscourse after listing of models. In order to view the frequencies, this study has proposed $627 \mathrm{MFs}$ after merging markers from Hyland's (2005) book: "Metadiscourse: Exploring Interaction in Writing" and "Textinspector.com". This study aims finding frequencies of MFs on the basis of propositional and non-propositional contents following the set parameters as discussed in the section of methodology. After having calculated frequencies, then identified frequencies have been categorized on the basis of propositional and non-propositional contents. Later, the calculated frequencies have been interpreted functionally. Lastly, as per functions the frequencies of four different newspaper editorials have been compared on the basis of similarities and differences. 
On the both quantitative and qualitative levels the present study has been conducted to probe into the following speculated research questions: 1) What are the frequencies of metadiscourse markers (MMs) in Pakistani English Newspaper Editorials (PENE)? 2) What are the functions of MMs in PENE? 3) What are the similarities and differences of metadiscourse features (MFs) among the national editorials of Pakistan: Dawn News (DN), The Express Tribune (TET), The Frontier (TF), and The News (TN)? This study has answered the speculated questions in this research.

\section{Review Literature}

In this section, this study briefly overviews the research studies that deal with MFs. Examples of major works and contributions are cited with the purpose of highlighting the stage at which metadiscourse has arrived and where the researcher's work fits in.

Metadiscourse refers to the "aspects of a text which explicitly organize a discourse or the writer's stance towards either its content or the reader" (Hyland, 2005, p. 14). It is largely based on the view that writing is a social activity dependent on the relations between writer, reader and the social context (Nystrand, 1986; Hyland, 2000; Thompson, 2001). The term metadiscourse was coined by Zellig Harris in (1959) to offer a way of understanding language in use, representing a writer's or speaker's attempts to guide a receiver's perception of a text. The concept has been further developed by writers such as Williams (1981), Vande Kopple (1985) and Crismore (1989), and collect together a range of discoursal features such as hedge, connectives and various forms of text commentary to show how writers and speakers intrude into their unfolding text to influence their interlocutor's reception of it. In fact, work by the sociologists Bateson (1972) and Goffman (1974) on frames was an important early development leading to linguistic conceptions of metadiscourse.

The following categorization in the current study the researcher points out that these two aspects of interaction, the interactive and the interactional, are essentially "two sides of the same coin" as highlighted by Thompson (2001, p. 61). Similarly, interactive resources such as conjunctions not only create structural links which assist comprehension, but also serve important interactional functions by anticipating, and perhaps deflecting, possible reader objections or counterclaims (Barton, 1994). The interactional metadiscourse thus represents the writer's overt performance in the text while the interactive metadiscourse more discreetly embodies it.

As a broad approach to metadiscourse, Hyland's metadiscourse model has been widely applied in previous studies of metadiscourse, so it has been presented in detail. According to Hyland (1998, 2004, 2005b, 2007, 2008, 2010, and 2011), and Hyland and Tse (2004), there are two levels of metadiscourse: interactive and interactional. Interactive resources assist to guide the reader through the text (Thompson, 2001, p. 58), by establishing discourse in accordance with the writer's anticipation of the reader's knowledge and the assessment of what the reader can recover from the text. Interactive resources include such categories as code glosses, transitional markers, frame markers, endophoric markers and evidential markers. Interactional resources comprise hedges, boosters, attitude markers, engagement markers and self-mentions (Hyland, 2010). Interactive metadiscourse is more related to what Halliday called the textual metafunction (Gillaerts and Van de Velde, 2010), while interactional metadiscourse is comparable to what Halliday called the interpersonal metafunction, dealing with the expression of the opinion of the writers, and their relationship and interaction with their readers.

\subsection{Supporting Studies to the Proposed Model}

In development of a new model, a detail of the following researches have helped in this research. The following studies have been enlisted ahead.

First, Boncea (2014) discussed the hedging structures which helped in constructing politeness strategies and mitigation in order to assess assertion's truth value. He also elaborated the distribution of hedging in form of lexical and grammatical patterns as MFs mentioned in the developed model. Another study by Švárová (2008) was conducted on hedges as politeness markers in spoken discourse in Brno, Czech. He highlighted hedging devices based on Willamova's (2005) categories mentioned broadly in developed model. As Willamova defined, the function of hedging device was as "typically used to express: disagreement, reservation, refusal, suggestion, uncertainty and indecision".

Secondly, the research study based on Boosters of interactional metadiscourse was considered in order to propose a new model of metadiscourse. Yazdani, Sharifi, and Elyassi (2014) recently conducted a research on exploring hedges and boosters in 9/11 English front page news articles. He discussed further divisions of hedges and boosters as taken in the proposed model.

Thirdly, a very broad study on metadiscourse was conducted in England by the Oskouei (2011) discussing the interactional variation in English and Persian. She worked on explaining the certainty and uncertainty markers 
in Magazine editorials. She also opened the distribution of attitude markers according to the analysis of the study. This said study was greatly in support of the current study.

A further research based on attitude markers as interactional category of metadiscourse was accomplished by Kindiki (2009) in Kenya on the pragmatic functions of attitude markers of the analysis of Kiitharka's language, Bantu. The researcher figured out an attitude markers under the names of: discourse/speech modifiers, discourse particles, pragmatic particles or discourse operator pragmatic markers. Similarly, Blagojevic and Negahdri (2009) conducted a research work on the use of attitude markers in discipline of academic research articles (RAs). He discussed the distribution of attitude markers in the following way: a) Adverbs and adverbial phrases functioning as sentence adverbials-disjuncts, b) Verb-modifying adverbs functioning as subjuncts-intensifiers, c) Adjectives functioning as subjective complement in sentences with expletive "it", d) Adjectives functioning as prenominal modifiers, e) Modal verbs expressing obligation, f) Nouns of specific semantic content (Blagojević, 2009). The distribution of attitude markers was considered in the proposed model of the current study.

Hyland (2011) proposed the categorization of interactional metadiscourse for disciplines and discourses in social interactional context for the purpose of constructing the knowledge. He specifically shared engagement markers in form of reader mention, directives, questions, knowledge reference and asides. This distribution was taken in the proposed model for the current study. Similarly, Gholami, Tajalli, and Shokrpour (2014) demonstrated the categorization of interpersonal metadiscourse in their research work. They specially highlighted the classification of frame markers in their study to express the functions of interactive metadiscourse. They also showed frame markers in terms of sequence markers, label stages, announce goals and topic shift. They further shared transition markers as additive, causal, adversative and temporal. This past study assisted in the current study considering Hyland's proposed categorization for proposing a new model.

As for as proposed model is concerned, Yang (2014) investigated the linguistic feature evidentiality as metadiscourse category in RAs of English of Applied Linguistics. He mainly divided evidential types into four major categories such as sensory, reporting, inferring and belief evidential. His categories were greatly supposed making a part of a new proposed model. The detail of division was accounted for in the proposed model.

Finally, Burneikaite (2009) mentioned endophoric markers as metadiscourse in detail. She categorized endophoric markers into five subcategories: non-linear text references, thesis level markers, chapter/section level markers, sentence level markers and vague markers. This distribution was marked in the current study as a part of new model for the analysis.

\subsection{Metadiscoursal Studies of Newspaper Editorials}

Linguistic is the study of variation of language, including phonetics, morphology, syntax, semantics, sociolinguistics, and pragmatics. The interest of Linguists in discourse in prior years is gradually shifting from the traditional focus on ideational dimension of texts and speech to the ways they function interpersonally (Hyland, 2004).

According to Isaac Afful (2014), a research conducted on analyzing of titles of feature articles in two different Ghanaian newspapers. Kuhi and Mojood (2012) conducted a research on contrastive study of metadiscourse, focusing on cross-linguistic study and generic conventions in English and Persian editorials. The said study helped in speculating research question no. 1.

Le (2004) confirmed how the elite newspaper, Le Monde, constructed active participation within its editorials' argumentation to establish its authority. More recently, Fu and Hyland (2014) explored some of the ways that interaction contributed to the success of two journalistic genres: popular science and opinion articles. After considering these studies, the functions of metadiscourse of said studies led toward the research question no. 2.

Dafouz-Milne (2008) carried on the research in metadiscourse in newspapers by exploring the role that MMs played in the construction and attainment of persuasion by examining two elite newspapers, the British The Times and the Spanish El Pal's. The said study assisted the researcher to raise the research question no. 3.

The current study attempted to address the objections of these previous studies. The prior studies were lacking in their corpus development, absence of corpus detail, insufficient size of data, lack of procedural analysis and inappropriate way to define frequencies of the MMs. The present study also criticized Congjun $\mathrm{Mu}$ ' (2010) work on national editorials due to the lack of corpus detail, inappropriate size of data and absence of recording information frequencies. 


\section{Research Methodology}

\subsection{Research Design}

The present study has dealt Interpersonal metadiscourse and its categorizations: interactive and interactional categories. The said categories have demanded a quantitative and a qualitative approaches. The former approach has been considered to find frequencies of MMs and, then to make comparison among the frequencies of Interpersonal metadiscourse, especially in PENE. The later approach has been considered for Interpersonal metadiscourse in order to develop a classification of metadiscourse and distinguishing propositional from non-propositional materials applicable to PENE.

In first category, the quantitative element of this research has found frequencies of MFs. The other quantitative aspect has made comparisons on the basis of similarities and differences keeping in view about its frequency of both interactive and interactional metadiscourse in PENE. Moreover, for this study 1000 editorials (250 from each newspaper: DN, TN, TF and TET) have been chosen.

The qualitative components of this work are both text- and theory-driven. This study has followed text-driven approach that has suggested a revised classification that has been considered the forms of Interpersonal metadiscourse identified in the said corpora. The newly developed categories have been discussed in detail and illustrated with the help of instances from PENE. This study is also theory-driven because it has emphasized the prior works of metadiscourse and has tried to display the issues which have been raised in this area. This study based on Interpersonal metadiscourse has contained some hurdles due to the fuzzy view about this concept and even variety of devices that can be accounted in the shed of this category. The current research has actually studied past works and has stated a couple of major difficulties: to differentiate both propositional and non-propositional contents that were, in fact, the main problem in works of metadiscourse, and also overlapping distributions of Interpersonal metadiscourse. This research has needed to attempt providing a clearer image of propositional and non-propositional contents by creating some boundaries in the form of proposed model for distinguishing the two.

\subsubsection{Proposed Model for This Study}

In order to cover qualitative component of the present research, after examining the list of studies' models as above mentioned the present model has been devised in order to cover major categories and all sub-categories of MFs. In this connection, this study has proposed a new model for metadiscourse analysis that has dealt: Interactive and Interactional categories. The proposed model has covered an extensive and maximum features of metadiscourse for the analysis purpose. See below. 
Table 1. Proposed model for this study

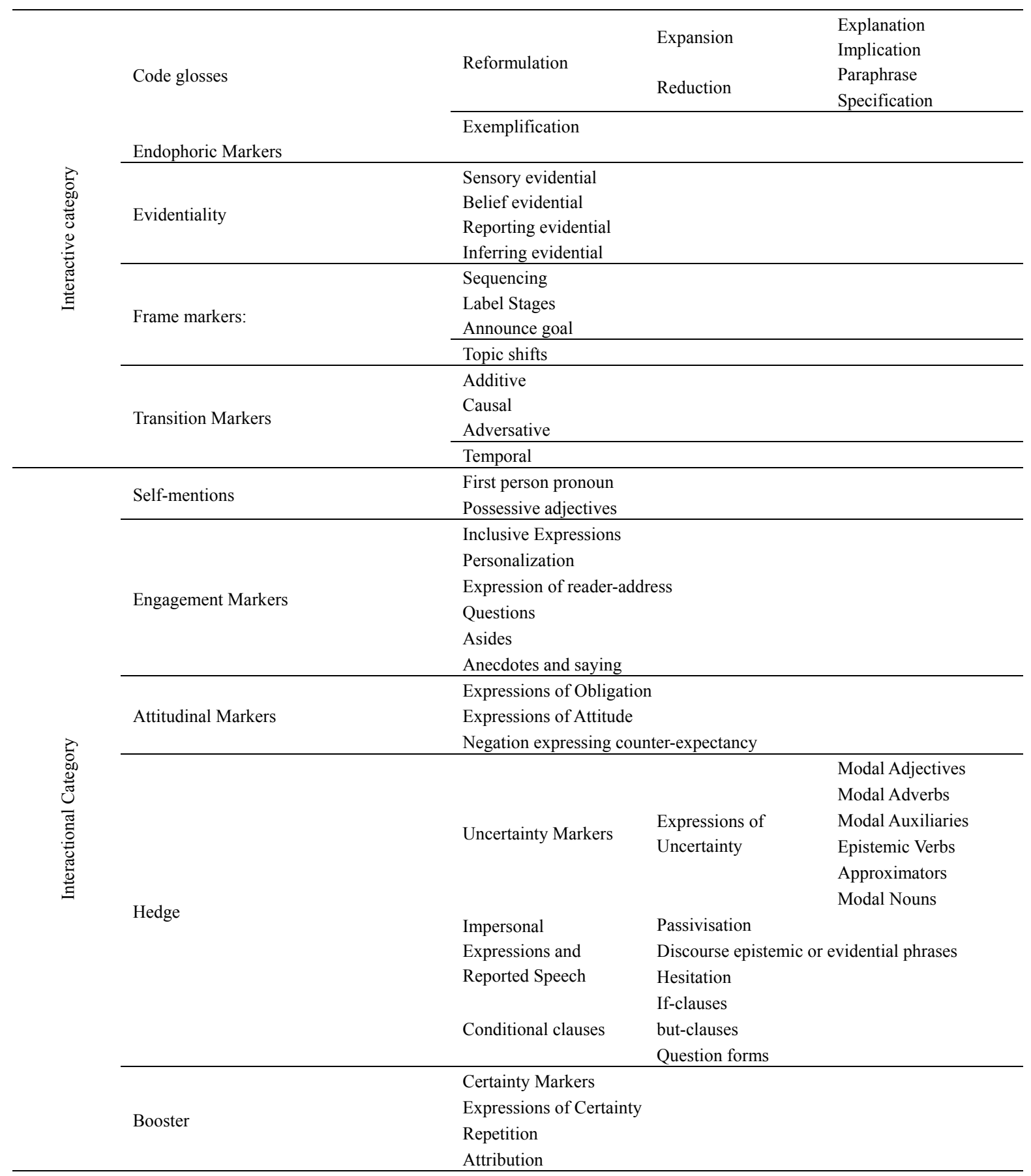

\subsubsection{Formation of List of Metadiscourse Markers}

Keeping in view the data analysis, this study has designed individual MFs that have been categorized into two categories: one was Interactive category and second was Interactional category. For each category, the lists of MMs have been planned by using two sources i.e., firstly, the features of interpersonal metadiscourse have been taken from textinspector.com. Secondly, the features of interpersonal metadiscourse have been taken from Hyland's (2005) book: Metadiscourse: Exploring Interaction in Writing. After refining the final lists, both lists have been merged together and duplicate markers have been removed from the final list of metadiscoursal categories such as interactive (i.e., textual) and interactional (i.e., interpersonal) metadiscourse. The detail of MMs is given below. 
Table 2. Formation of final lists of metadiscourse markers

\begin{tabular}{|c|c|c|c|c|}
\hline Categories & Sub-Categories & Textinspector.com & Hyland (2005) & Merged Markers \\
\hline \multirow{9}{*}{$\begin{array}{l}\text { INTERACTIVE } \\
\text { MARKERS }\end{array}$} & Code glosses & 18 & 25 & 28 \\
\hline & Endophorics & 14 & 20 & 34 \\
\hline & Evidentials & 29 & 7 & 36 \\
\hline & $\begin{array}{l}\text { Frame Markers: } \\
\text { Sequencing }\end{array}$ & 39 & 26 & 52 \\
\hline & Frame Markers: & \multirow{2}{*}{12} & \multirow{2}{*}{16} & \multirow{2}{*}{22} \\
\hline & Label stages & & & \\
\hline & $\begin{array}{l}\text { Frame Markers: } \\
\text { Announce goals }\end{array}$ & 19 & 15 & 34 \\
\hline & $\begin{array}{l}\text { Frame Markers: } \\
\text { Shift topic }\end{array}$ & 0 & 13 & 13 \\
\hline & Transition Markers & 48 & 48 & 51 \\
\hline \multirow{6}{*}{$\begin{array}{l}\text { INTERACTIONAL } \\
\text { MARKERS }\end{array}$} & Self-mentions & 6 & 11 & 11 \\
\hline & Engagement Markers & 21 & 79 & 86 \\
\hline & Boosters & 39 & 65 & 81 \\
\hline & Attitude markers & 26 & 64 & 72 \\
\hline & Hedges & 47 & 101 & 107 \\
\hline & Total & 318 & 490 & 627 \\
\hline
\end{tabular}

The final column containing 627 individual MMs have been finalized for the data analysis. The lists of interactive and interactional categories are given in Appendix A.

\subsubsection{Proposed Metadiscoursal Features: Interactive and Interactional Categories}

The present study has proposed both new schemes of individual Interactive and Interactional MFs. The above mentioned table has already shown the distributions of both major categories: firstly Interactive and lastly Interactional metadiscourse. The final lists of the new schemes of MMs have been provided in Appendix A.

\subsection{Development of Corpus}

After having proposed model on metadiscourse, the corpus for the present study has been developed. The data has been lifted in form of editorials from online sources that have talked over up-to-date problems which have affected the society in conveying that have shared views belonging to issues and that they have shown affiliation to educated audience. In order to depict the clear picture to the reader that some parameters have been set in selection of editorials under the following standards:

1) They are relative with different networks of newspaper or contain unlike publisher.

2) They are issued on daily basis as compared to weekly basis.

3) The chosen editorials are partially signed and partially unsigned, and are likely written by the editorialists in order to represent the editorial board and to some extent individuals.

4) The language of editorials is an argumentative or criticism in nature.

5) They are available on internet, especially on their websites.

6) They are found in English language.

As for as data size is concerned, 1000 editorials from PENE have been collected. The distribution of 250 editorials from each newspaper has been taken equally as discussed earlier.

\subsection{Analysis of the Study}

As for as analysis is concerned, all taken newspaper editorials have been examined under the proposed model of metadiscoursal categories: Interactive and Interactional markers.

For the current study, a number of techniques have been developed to analyze MFs out of PENE. First, the current research has practiced a new proposed model of metadiscourse, which has been classified metadiscourse into two categories: 1) Interactive metadiscourse and 2) Interactional metadiscourse. The former category Interactive metadiscourse has included frame markers, evidential, endophoric markers, code glosses and transition markers. The latter category Interactional metadiscourse has comprised boosters (expression of certainty), hedges (expression of uncertainty), attitude markers, self-mentions and engagement markers. Second, the most important thing of this study has a development of lists of MMs which have been borrowed from the 
sources discussed earlier.

Thirdly, this study has developed metadiscoursal expressions of each metadiscoursal category which has been processed in software (Antconc.3.4.4.0) for having numerical results. The significance of these expressions has made a new way for the future researches. In order to have an innovative way, the markers have been devised in form of an expressions and they have been used in order to check all required MMs at once. For the purpose of checking frequencies of MFs and the analysis of data, the text processor (Antconc.3.4.4.0, 2014) has been used. Then, the items taken to be metadiscourse have been identified and categorized in the texts based on the proposed model of metadiscourse has contained the said categories, and the analysis has found all MMs which have been used most frequently and less frequently in interactive and in interactional categories, but have ignored those markers which have not been found even a single time in a single file of the corpus. In order to maintain the quality, the researcher has manually checked out the identified markers on the basis of propositional and non-propositional contents. See developed metadiscoursal expressions in Appendix B.

\section{Results}

This study has presented results and discussion for data analysis. The present research is both quantitative and qualitative in nature. The quantitative approach has been set to present numerical results in form of frequencies based on propositional and non-propositional contents. The second aim of this approach has been set to compare the frequencies of propositional and non-propositional metadiscourse on the basis of similarities and differences. On the other hand, the qualitative approach has been set to interpret the numerical results functionally. As for as quantitative approach is concerned, the proper distribution of propositional and non-propositional MMs out of PENE (for example, DN, TN, TET and TF) has been presented in table below.

Table 3. Distribution of frequencies of interactive and interactional markers

\begin{tabular}{lllllll}
\hline \multirow{2}{*}{ No. of Newspapers } & \multicolumn{2}{l}{ Interactive Markers } & \multicolumn{2}{l}{ Interactional Markers } & \multicolumn{2}{l}{ Accumulated Markers } \\
& Propositional & Metadiscourse & Propositional & Metadiscourse & Propositional & Metadiscourse \\
\hline Dawn News & 3,048 & 4,840 & 926 & 5,376 & 3,974 & 10,216 \\
The Express Tribune & 2,459 & 4,646 & 581 & 3,809 & 3,040 & 8,455 \\
The Frontier & 4,585 & 8,153 & 1,605 & 7,834 & 6,190 & 15,987 \\
The News & 3,319 & 4,732 & 1,253 & 3,232 & 4,572 & 7,964 \\
\hline
\end{tabular}

As far as interactive metadiscourse results are concerned, the frequency of MFs is seen in all editorials but the greater amount of interactive markers is found in corpus of TF. On the other hand, in the corpus of TF in which the most frequent group interactional markers has been observed. The detail of results of MFs of each corpus is given below.

Table 4. Mutual Results of all Corpora

\begin{tabular}{|c|c|c|c|c|c|c|c|c|c|}
\hline \multirow[t]{2}{*}{ Categories } & \multirow[t]{2}{*}{ Sub-Categories } & \multicolumn{2}{|c|}{ The Frontier } & \multicolumn{2}{|c|}{ The Dawn } & \multicolumn{2}{|c|}{$\begin{array}{l}\text { The Express } \\
\text { Tribune }\end{array}$} & \multicolumn{2}{|c|}{ The News } \\
\hline & & Pro & Meta & Pro & Meta & Pro & Meta & Pro & Meta \\
\hline \multirow{9}{*}{$\begin{array}{l}\text { INTERACTIVE } \\
\text { MARKERS }\end{array}$} & Code glosses & 2 & 504 & 20 & 628 & 29 & 509 & 17 & 426 \\
\hline & Endophorics & 35 & 327 & 129 & 134 & 37 & 165 & 73 & 221 \\
\hline & Evidentials & 24 & 748 & 37 & 280 & 23 & 240 & 330 & 940 \\
\hline & Frame marker: Sequencing & 170 & 2,230 & 369 & 1,237 & 398 & 900 & 494 & 1,186 \\
\hline & Frame markers: Label Stages & 13 & 253 & 103 & 75 & 0 & 190 & 20 & 97 \\
\hline & Frame markers: Announce goal & 10 & 127 & 23 & 73 & 8 & 71 & 27 & 54 \\
\hline & Frame markers: Topic shifts & 130 & 480 & 126 & 292 & 155 & 283 & 81 & 171 \\
\hline & Transition Markers & 4,201 & 3,484 & 2,241 & 2,121 & 1,809 & 2,288 & 2,277 & 1,637 \\
\hline & Total & 4,585 & 8,153 & 3,048 & 4,840 & 2,459 & 4,646 & 3,319 & 4,732 \\
\hline \multirow{6}{*}{$\begin{array}{l}\text { INTERACTIONA } \\
\text { L MARKERS }\end{array}$} & Self-mentions & 567 & 915 & 67 & 184 & 82 & 339 & 372 & 221 \\
\hline & Engagement Markers & 888 & 2,369 & 435 & 1,480 & 318 & 1,056 & 576 & 929 \\
\hline & Boosters & 51 & 1,527 & 111 & 1,325 & 34 & 748 & 116 & 587 \\
\hline & Attitude Markers & 23 & 791 & 30 & 761 & 79 & 331 & 66 & 334 \\
\hline & Hedges & 76 & 2,232 & 283 & 1,626 & 68 & 1,335 & 123 & 1,161 \\
\hline & Total & 1,605 & 7,834 & 926 & 5,376 & 581 & 3,809 & 1,253 & 3,232 \\
\hline
\end{tabular}


The above mentioned results of Interactive markers have been presented graphically in order to disclose a vivid image of the use of MMs in PENE by the editorialists. In given below graph, it has been seen that the frequent use of Transition and Sequencing markers has been observed out of all PENE. In this graph, there has only been portrayed non-propositional markers graphically.

\section{INTERACTIVE METADISCOURSE}

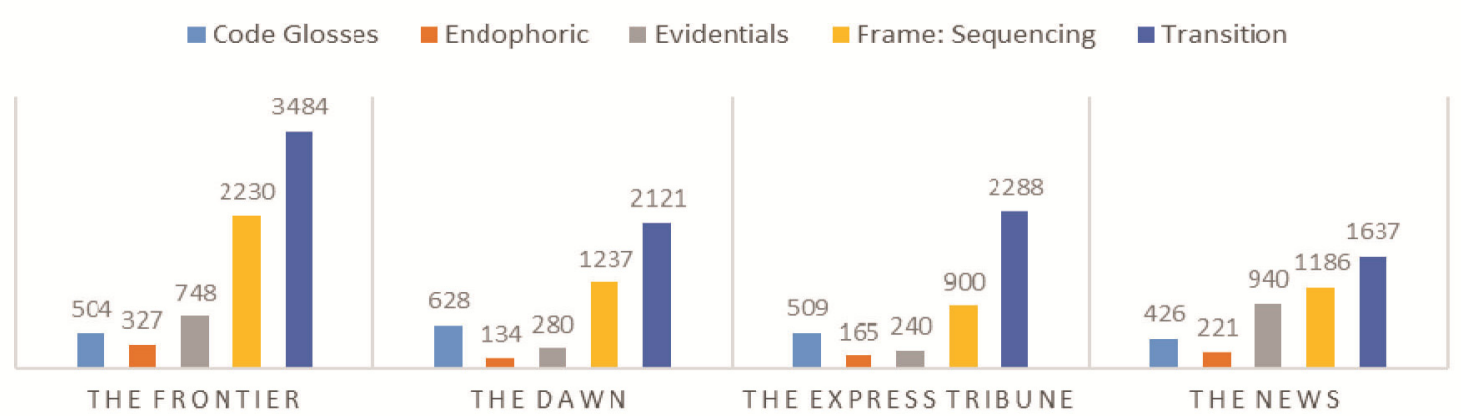

Figure 1. Results of interactive metadiscourse

As for as Interactional sub-categories are concerned, the above mentioned results have been presented graphically in order to disclose a vivid image of the MMs in PENE by the editorialists. In given below graph, it has been seen that the most frequent use of engagement, emphatics and hedges categories has been noticed on the basis of propositional and non-propositional out of all PENE. In given below, the non-propositional markers have been considered and presented graphically.

\section{INTERACTIONAL METADISCOURSE}

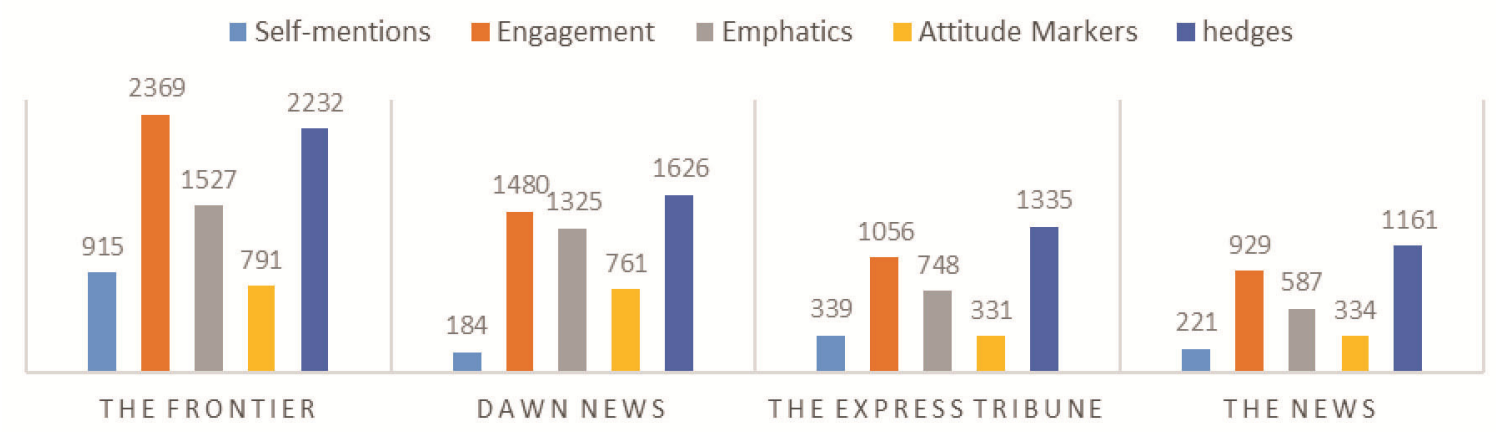

Figure 2. Results of interactional metadiscourse

\section{Discussion}

The single most striking observation emerged from the data comparison is the occurrences of interactive and interactional markers in corpus of TF. The detail of results of individual corpus is seen: firstly the sub-categories of interactive category such as sequencing and Transition markers have been seen in greater amount as compared to the other corpora. Secondly, the sub-categories of interactional category such as self-mention, engagement markers, boosters, attitude markers and hedges have been found more frequently than other corpora As above mentioned in table, the summed up results have been shown on the basis of propositional and non-propositional which have been manually noted by studying each marker in a given corpus.

Similarly, as far as the results of TF are concerned, the sub-category Transition markers in interactive metadiscourse has been used frequently. In case of interactional category, the most frequent sub-category is Engagement markers. In conclusion, interactive sub-category is used more frequently as compared to interactional metadiscourse. This thing shows that the editorials' writing in Pakistan is reader-friendly not 
writer-friendly.

Likewise, in corpus of TN the greater amount of markers of sub-category Transition markers is seen in interactive category. In interactional category, the most frequent use of MMs is used in sub-category Hedges. Overall, the editorialists have used more interactive markers than interactional markers in their editorials. The same conclusion is inferred as the corpus TF draws.

More likely, in corpus of DN the sub-category Transition markers is frequently used in editorials of the said corpus. In case of interactional metadiscourse, the most frequent sub-category hedges is used in corpus of DN. This frequent use of interactive metadiscourse is seen more than interactional markers in the particular corpus. The same conclusion on the basis of results is drawn as inferred by TF and TN.

Moreover, in corpus of TET the greater use of sub-category Transition markers in interactive metadiscourse is used by the editorialists. The most frequent sub-category hedges of interactional metadiscourse is used. Similarly, another sub-category Engagement markers is frequently used. Overall, in this corpus, the interactive markers have been used more frequently as compared to interactional markers. Again, the similar conclusion is marked as inferred by TF, TN and DN.

As above tabulated, in response to the results it has been observed that the greatest amount of interactive markers is seen in the corpus of TF, and the most frequent markers of sub-category Transition markers and the frequent category Sequencing markers are seen in all corpora. The most frequent markers of sub-categories Engagement markers and Hedges are only seen in the corpus of TF. In the next section, the functions of MMs are exemplified under the categories: Interactive and Interactional metadiscourse.

\subsection{Interactive Metadiscourse}

\subsubsection{Code Glosses}

The function of code glosses is providing additional information through rephrasing, illustrating or explaining. It shows the writer's proposition regarding the cognitive environment of the reader. According to Hyland (2007), code glosses are distributed into exemplification and reformulation. The following examples are given below:

1) As per the report, practices such as forced labour, debt bondage and forced marriage all qualify as modern slavery. Experts say that over the years, the number of slaves has not increased, but more data has become available. (Dawn News file no. 65)

In example (1), the use of such as has shown the additional meanings through such exemplified word. Using this marker, the writer has exposed further elaboration in the proposition.

2) The point-scoring approach from both sides also created tension. For instance, the government team committed a big blunder when they portrayed opposition's offer to drop the name of prime minister from the TORs as its success. (The News file no. 63)

In above mentioned example (2), the writer has employed marker for instance in order supply further meanings in the propositional content for the readers. This marker is used to quote some previous truths proving the current affairs authentically and persuasively for the readers. These underlined markers are treated as MMs because of their usage in the sentences.

Implication functions to make a conclusion or sums up the prior segment. An instance is given below:

3) In other words, the political society uses a coercive approach whereas the civil society employs a discursive approach. (The News file no. 14)

In example (3), the significant use of marker In other words as a concept of equivalence is seen between statements that are helpful in order to rephrase the conclusion as per writer's views keeping readers away from statement in this way.

\subsubsection{Endophoric}

Endophoric markers as metadiscoursal devices refer to information which are expressed in the text such as given below, noted above, for example and etc. These markers signify additional material and make accessible to the readers in order to show the intentions of the writer, and fulfill the recovery of his meanings. The following example is seen below:

4) For example, the wrestler Inamullah was denied entry to the Olympic qualifying round last month due to the sheer ineptness of the administrators as he failed to reach the venue of the qualifying event. (The Express Tribune file no. 129) 
In example (4), using for example shows something has happened earlier in another text but the writer is putting something in current writing what has said or happened before for developing reader's mind immediately. This kind of use of this marker is considered as MMs.

\subsubsection{Evidential}

Evidentials are devices of metalinguistic representations in order to show ideas taking from another source and assist in establishing the subject's authorial command. Evidentials indicate to the information in which persuasive goal is achieved by the writer's stance. Evidential is further categorized into sensory, belief, reporting and inferring evidentials. The following is example:

5) But when I look at Japan, $\underline{\text { I see }}$ plenty of evidence that neither individual behavior nor free-market policy is the main reason for poverty. (The Frontier file no. 246)

In above mentioned example (5), using I see shows writer's view about reality of the current events or what has happened earlier. As in above example (4), the writer is getting involved personally in order to involve the readers by exposing evidences about what is going on.

6) Admittedly, Afridi has the unfortunate tendency to often give inappropriate statements, but this was not one of those times. (The Express Tribune file no. 194)

In above example (6), admittedly has been employed as adjuncts by the editorialist showing his individuality through such adverbs. In this example, the writer has put himself/herself as an authority in front of the readers. The writer has shown himself as the opinion holder in the proposition for the readers. This marker is considered as MMs.

\subsubsection{Frame Markers}

Frame Markers refer to sequences, text stages, or discourse acts. These markers frame the propositional material in order to make it interesting and attractive for the readers. By the use of these markers, the writer makes his writing beautiful, conveys his goals and gives the sequence of ideas appropriately. Frame markers such as finally, to conclude, the aim, I would like to, I wish, firstly and etc. have been seen in below examples.

In this study, frame markers are further subcategorized into announce goals, sequencing, labeling and topic shifting. The following are examples below:

7) Lastly, I would like to get something straight. While Egypt is on the path to democracy the road remains long and strewn with boulders, as the president admits. (The Frontier file no. 190)

In above example (7), I would like to has been seen in this study which has shown the writer's intentions how he foregrounds the reader and lets the reader to figure out the significance of the propositional material. This marker has been employed by the writer to announce goals and purposes personally.

8) Preservation of history has two major benefits: firstly, it shows that we value our heritage and are concerned about holding on to it. (Dawn News file no. 35)

In example (8), the writer has used a sequence marker making writing more dimensional and directional for the readers. The use of firstly has shown the writer's opinions how he has organized different arguments and ideas through the said marker.

\subsubsection{Transition Markers}

Transition markers are in form of conjunctives and conjunctions which assist the readers to seek reasonable connection between propositions. These markers act as adverbial phrases and assist readers in an interpreting pragmatic relations between arguments and events. A number of categorizations have been proposed by the related authorities, covering the categorization proposed by Halliday and Hasan (1976):

Additive markers (i.e., for example, moreover, similarly) as metadiscourse devices establish a connection in an argument in order to interact with readers through text for persuasion. The following examples are given below:

9) Moreover, particular attention must be given to rescuing minors from slavery. (Dawn News file no. 65)

In above example (9), using Moreover by the writer has directed and organized an argument appropriately in the propositional content.

Causal markers (i.e., as a result, it follows that, therefore) refer to the consequences of a cause in an argument. The following examples are given below:

10) Therefore, the final outcome of "Panama politics", be zero plus zero: zero. (The News file no. 131) 
In example (10), the use of therefore has been practiced by the writer to show the consequences of the matter that is under discussion.

Adversative transitions (i.e., but, however, although, nevertheless) are used to show conflict, contradiction concession, dismissal, emphasis and replacement.

11) Nevertheless, this is a step in the right direction and it is hoped that the textbooks will include such topics as gender equality and the rights of minorities as well. (The Express Tribune file no. 27)

Similarly, in example (11) nevertheless has been employed by the writer where there is a need to show different views as different arguments. This kind of marker is considered as MMs.

Temporal markers is a type of transition (i.e., second, then, lastly) "are used to signal a chronological or logical sequence." The use of temporal transition has been mentioned below in examples:

12) Finallv, Fata communities will not be rebuilt by economic incentives alone-there has to be a sense of local ownership in the rebuilding and revival of post-conflict areas. (Dawn News file no. 70)

In above example (12), using finally has been used in propositional content showing logical connection between arguments. This marker works as sequential transition which organizes ideas effectively for the readers. This marker has been regarded as MMs.

\subsection{Interactional Metadiscourse}

\subsubsection{Self-mentions}

The function of self-mention shows the use of possessive adjectives (i.e., my, our) and first person pronouns (i.e., I, we) to present information. In this study, self-mention shows the use of first person pronouns. This study has employed the forms of first person and its possessive forms for presenting information. The following example is given below.

13) Sadly, I must state that all of these high and mighty appointees meted out a step-motherly treatment to Fata and never contributed towards its development. (The News file no. 131)

In above mentioned instance (13), the writer has used first personal pronoun $I$ in order to show his presence and personally criticized those appointees who did not fulfilled their duties properly for the development of Fata. The writer has shown his presence as a criticizer who has been pinched by the negligence of the appointees. He has consciously employed this marker to express his sorrowful feelings. This marker is considered as MMs.

\subsubsection{Engagement Markers}

The function of engagement markers is addressing readers, taking their attentions selectively, and anticipating their expected problems, considering their presence as participants with the assistance of second personal pronoun, questions forms, asides, and imperatives (Hyland, 2004). The following examples are given below.

14) $\underline{W}$ will not give any of them the oxygen of publicity. (The Express Tribune file no. 235)

In above mentioned example (14), where we has been used inclusively. It is also showing the writer's wish by saying that he inclusively with the rest of people will not let anyone to get benefits through advertisement. Therefore, it is marked as being an inclusive expression. So, it is grouped in "personalization".

\subsubsection{Attitudinal Markers}

Attitude markers show the way of expressing or commenting of speakers or writers on propositional material or content what belong to the real world. The current study has made texts based analysis on the basis of propositional and non-propositional attitudinal traits as Hunston and Rose do. Hunston and Thompson (2000) have brought the term evaluation into use in their study.

15) Germany will also have to develop a much more comprehensive and forceful foreign policy for Northern Africa and the Middle East. (The Frontier file no. 72)

In above mentioned example (15), have to has been employed by the author to indicate an obligation and anticipate a suggestion about the circumstances in which action is done, is regarded as expressions of obligation.

\subsubsection{Hedges}

Hedges refer to the uncertainty, possibility and negativity in the content. Hedges help the writer to create politeness, probability and ambiguity in order to pursue readers through his writing. In order to support the present study, the use of hedges expresses the reluctance of the writer to show the category of the propositional information (Hyland, 1996, 2010; Holmes, 1988), to allow the writers in order to show their knowledge in an 
intellectual way and to construct the dual authorial identity of "humble servants" of their originators of new knowledge and disciplines (Myers, 1989, p. 4). See examples below:

16) There seems to be an ever-present ruthlessness when it comes to the treatment of Afghan refugees in Pakistan. (The Express Tribune file no. 39)

In an instance (16), the use of hedge seems has been seen in this study. The use of hedge has been expressed the tentativeness and possibility at writer's end in his/her writing.

Question form is a technique to gain the attention of the audience or readers. In this study, question forms have been seen as a way to catch the minds of the readers. The following example taken from corpus is seen below:

17) Why have there been no enrolment drives? (Dawn News file no. 77)

In example (17), the use of question form has been observed in propositional content by the writer to involve the readers towards the serious matter as to get their opinions and letting them to judge. This technique has been accounted for holding opinions of the readers. This technique is considered as MFs.

\subsubsection{Boosters}

Certainty markers refer to surety, emphasis, certainty, validity, obligation, probability and the telling truth in propositional material. The term Certainty markers has been replaced by the term Boosters as given in Hyland's (2005) model and the term emphatics as given (Crismore and Farnsworth, 1989; Vande Kopple, 2002). The following examples are given below:

18) The funny thing is that earlier in the day, King Salman was present at the airport to receive the leaders of other Gulf nations. Obama obviously had to swallow the snub. (The Frontier file no. 231)

Adverb has been used to indicate certainty in above example (18), the writer has employed obviously as certainty marker showing certainty about the issue to the readers.

\section{Conclusion}

The conclusion of the study was made on theoretical and empirical foundation. In case of theoretical foundation, this study was designed determining the fair image of both interactive and interactional categories in forms of its distinction- the distribution between the propositional and non-propositional content, a new classification of ultimately interpersonal metadiscourse was designed taking account the prevailing works. This newly designed categorizations attempted to set a parameters regarding the vague nature of the sub-categories of major interpersonal metadiscourse. In case of empirical foundation, the findings of this study showed that the influential metadiscourse category in editorials genre was interactive category, and the predominant features were sequencing markers, and transitional markers- a subcategories of interactive category. More precisely, the major category Interactional markers contains the higher outcomes of MFs in the editorials of TF, but the interactional features are less perceived in the remaining corpora (i.e., DN, TN, and TET).

The boundaries of this study as limits are supposed, one of the limitations of this research is the relatively unequal size of chosen corpora data files for purpose of analysis. The current study opens a new gateway as having larger data or even smaller data in future for further research, because this study contains 1000 editorials and finds functions of Interpersonal metadiscourse in it, finds type of functions as frequency and also finds similarities and differences of type of metadiscoursal functions in all corpora. First time, taking larger data is analyzed in order to explore the Interpersonal metadiscourse functions in the context; however, the analysis was conducted using software as above mentioned. In this connection, keeping in view the time limitation, a number of texts (i.e., 1000 editorials) were taken in corpus, but their individual size of all files were short and easily considerable for analysis. Having larger data for this study, it was more than enough to generalize the results and display overall differences in the practice of certainty devices, uncertainty devices and engagement devices in all corpora.

Another limitation was in discussion section where evidential was not discussed or even focused in this study due to lack of background studies on the distribution of evidential markers. The limitation of this study is to avoid gender base analysis of editors, and has taken DN, TN, TET and TF newspaper editorials only in Pakistan. Future research can be carried on relevant contextual elements (editors and particular magazines, press, online blogs) in order to highlight the functions.

\section{References}

Afful, I. (2014). An Analysis of Titles of Feature Articles in Two Selected Ghanaian Newspapers. English for Specific Purposes World, 43(15). 
Barton, D. (1994). Literacy: An Introduction to the Ecology of Written Language. Oxford: Blackwell.

Bateson, G. (1972). Steps to an Ecology of Mind: Collected Essays in Anthropology, Psychiatry, Evolution, and Epistemology. Chicago: University of Chicago Press.

Blagojevic, S. (2009). Expressing attitudes in academic research articles written by English and Serbian authors. FACTA UNIVERSITATIS-Linguistics and Literature, 7(1), 63-73.

Boncea, I. (2014). Hedging Patterns Used as Mitigation and Politeness Strategies. Annals of the University of Craiova. Series: Philology, English, (2), 7-23.

BURNEIKAITĖ, N. (2009). Endophoric Markers in Linguistics Master's Theses in English L1 \& L2. Man \& the Word/Zmogus ir zodis, 11(3).

Crismore, A. (1989). Talking with Readers: Metadiscourse as Rhetorical Act. New York: Peter Lang Publishers.

Crismore, A., \& Farnsworth, R. (1990). Metadiscourse in popular and professional science discourse. The Writing Scholar: Studies in the Language and Conventions of Academic Discourse (pp. 45-68). Newbury Park, CA: Sage.

Fu, X., \& Hyland, K. (2014). Interaction in two Journalistic Genres: A Study of Interactional Metadiscourse. English Text Construction, 7(1), 122-144. https://doi.org/10.1075/etc.7.1.05fu

Gholami, M., Tajalli, G., \& Shokrpour, N. (2014). An investigation of metadiscourse markers in English Medical texts and their Persian translation based on Hyland's model. European Journal of English Language and Literature studies, 2(2), 1-41.

Gillaerts, P., \& Van de Velde, F. (2010). Interactional Metadiscourse in Research Article Abstracts. Journal of English for Academic Purposes, 9(2), 128-139. https://doi.org/10.1016/j.jeap.2010.02.004

Goffman, E. (1974). Frame Analysis: An Essay on the Organization of Experience. Harvard: Harvard University Press.

Halliday, M. A., \& Hasan, R. (1976). Cohesion in Spoken and Written English. London: Longman.

Holmes, J. (1988). Doubt and certainty in ESL textbooks. Applied linguistics, 9(1), 21-44. https://doi.org/10.1093/applin/9.1.21

Hunston, S. \& G. Thompson (2000). Evaluation: An introduction. In S. Hunston \& G. Thompson (Eds.), Evaluation in text: Authorial stance and the construction of discourse (pp. 1-27). Oxford: Oxford University Press.

Hyland, K. (1996). Writing without conviction? Hedging in science research articles. Applied Linguistics, 17(4), 433-454. https://doi.org/10.1093/applin/17.4.433

Hyland, K. (1998). Persuasion and Context: The Pragmatics of Academic Metadiscourse. Journal of Pragmatics, 30, 437-455. https://doi.org/10.1016/S0378-2166 (98)00009-5

Hyland, K. (2000). Disciplinary discourses: Social interaction in academic genres. Harlow, UK: Longman.

Hyland, K. (2004). Patterns of Engagement: Dialogic Features and L2 Student's Writing. In L. Ravelli \& R. Ellis (Eds.), Academic Writing in Context: Social-functional Perspectives on Theory and Practice. London: Continuum.

Hyland, K. (2005). Metadiscourse: Exploring Interaction in Writing. London: Continuum.

Hyland, K. (2005b). Stance and Engagement: A Model of Interaction in Academic Discourse. Discourse Studies, 7(2), 173-191. https://doi.org/10.1177/1461445605050365

Hyland, K. (2007). Applying a Gloss: Exemplifying and Reformulating in Academic Discourse. Applied Linguistics, 28(2), 266-285. https://doi.org/10.1093/applin/amm011

Hyland, K. (2008). Persuasion, Interaction and the Construction of Knowledge: Representing Self and Others in Research Writing. International Journal of English Studies, 8(2), 1-23.

Hyland, K. (2010). Constructing Proximity: Relating to Readers in Popular and Professional Science. Journal of English for Academic Purposes, 9, 116-127. https://doi.org/10.1016/j.jeap.2010.02.003

Hyland, K. (2011). Disciplines and Discourses: Social Interactions in the Construction of Knowledge. Writing in Knowledge Societies. Perspectives on Writing, 193-214.

Hyland, K., \& Tse, P. (2004). Metadiscourse in Academic Writing: A Reappraisal. Applied Linguistics, 25(2), 
156-177. https://doi.org/10.1093/applin/25.2.156

Kindiki, S. K. (2009). Pragmatic functions of attitude markers in Kiitharaka.

Kuhi, D., Mojood, M., \& Branch, M. (2012). A Contrastive Study of Metadiscourse in English and Persian Editorials. The Journal of Applied Linguistics, 5(1), 137-162.

Le, E. (2004). Active Participation within Written Argumentation: Metadiscourse and Editorialist's Authority. Journal of Pragmatics, 36(4), 687-714. https://doi.org/10.1016/S0378-2166(03)00032-8

Milne, E. (2008). The Pragmatic Role of Textual and Interpersonal Metadiscourse Markers in the Construction and Attainment of Persuasion: A Cross-Linguistic Study of Newspaper Discourse. Journal of Pragmatics, 40(1), 95-113. https://doi.org/10.1016/j.pragma.2007.10.003

$\mathrm{Mu}$, C. (2010). A Contrastive Analysis of Metadiscourse in Chinese and English Editorials [J]. Foreign Language Learning Theory and Practice, 4, 006.

Myers, G. (1990). Writing Biology: Texts in the Social Construction of Scientific Knowledge. Madison: University of Wisconsin Press.

Negahdari, A. (2009). Attitude Markers in English and Persian. University of Khorasgan Azad.

Nystrand, M. (1986). The Structure of Written Communication. Orlando: Academic Press.

Oskouei, L. K. (2011). Interactional variation in English and Persian: A comparative analysis of metadiscourse Features in magazine editorials (Doctoral dissertation, University of East Anglia Norwich).

Švárová, J. (2008). Politeness markers in spoken language (Doctoral dissertation, Masarykova univerzita, Pedagogická fakulta).

Thompson, G. (2001). Interaction in Academic writing: Learning to Argue with the Reader. Applied Linguistics, 22(1), 58-78. https://doi.org/10.1093/applin/22.1.58

Vande Kopple, W. J. (1985). Some Explanatory Discourse on Metadiscourse. College Composition and Communication, 36, 82-93. https://doi.org/10.2307/357609

Vande Kopple, W. J. (2002). Metadiscourse, discourse, and issues in composition and rhetoric. In E. L. Barton \& G. Stygall (Eds.), Discourse studies in composition (pp. 91-113). Cresskill and NJ: Hampton Press.

Wilamova, S. (2013). On the function of hedging devices in negatively polite discourse. Brno studies in English, 31(1), S11.

Williams, J. M. (1981). Style: Ten Lessons in Clarity and Grace. New York: Harper Collins Publishers.

Yang, L. (2014). Evidentiality in English research articles of applied linguistics: from the perspective of metadiscourse. Journal of Language Teaching and Research, 5(3), 581-591. https://doi.org/10.4304/jltr.5.3.581-591

Yazdani, S., Sharifi, S., \& Elyassi, M. (2014). Exploring hedges and boosters in 9/11 English front page news articles. Asian Journal of Research in Social Sciences and Humanities, 4(3), 301. 


\section{Appendix A}

Table 5. Proposed metadiscoursal features: interactive category

\begin{tabular}{|c|c|c|c|c|c|c|c|}
\hline $\begin{array}{l}\text { Code } \\
\text { Glosses }\end{array}$ & certain that & Must & (In) Section X & Believe & Approximately & in my view & Sometimes \\
\hline for example & Certainly & Never & (In) the $X$ chapter & Believes & Argue & in this view & Somewhat \\
\hline ( ) & Certainty & no doubt & (In) the X part & Cite & Argued & in our view & Suggest \\
\hline $\begin{array}{l}\text { as a matter } \\
\text { of fact }\end{array}$ & Clear & Obvious & (In) the $\mathrm{X}$ section & Cited & Argues & $\begin{array}{l}\text { in our } \\
\text { opinion }\end{array}$ & Suggested \\
\hline Called & Clearly & Obviously & (In) This chapter & Cites & Around & Indicate & Suggests \\
\hline defined as & Conclusively & of course & (In) This part & Claim & Assume & Indicated & Suppose \\
\hline e.g. & Decidedly & Prove & (In) This section & Claims & Assumed & Indicates & Supposed \\
\hline for instance & Definite & Proves & Chapter & Demonstrate & Believed & Largely & Supposes \\
\hline i.e. & Demonstrate & Proved & discussed above & Demonstrates & Broadly & Little & Suspects \\
\hline Mean & Definitely & Realized & discussed before & Established & Claim & Likely & Suspect \\
\hline $\begin{array}{l}\text { in other } \\
\text { words }\end{array}$ & Demonstrates & Realizes & discussed below & found that & Claims & May & tended to \\
\hline In fact & Demonstrated & Realize & discussed earlier & Literature & certain extent & Mainly & tend to \\
\hline Known as & Determine & Should & discussed later & point out & Claimed & Might & tends to \\
\hline Indeed & Doubtless & Really & Example X & point to & certain amount & Maybe & Typical \\
\hline Or & Doubt & Shown & Example & points out & certain level & Mostly & $\begin{array}{l}\text { to my } \\
\text { knowledge }\end{array}$ \\
\hline Namely & Essential & Show & Figure & points to & Couldn't & $\begin{array}{l}\text { not } \\
\text { understood }\end{array}$ & Typically \\
\hline Say & Established & Shows & Fig & Prove & Could & Often & Uncertainly \\
\hline $\begin{array}{l}\text { put another } \\
\text { way }\end{array}$ & Establish & Showed & Noted & Proves & Doubtful & Ought & Uncertain \\
\hline such as & even if & Surely & Page & Quote & Doubt & on the whole & Unclearly \\
\hline Specifically & Evidently & Sure & P. X & Quoted & Estimate & Plausible & Unclear \\
\hline that means & Evident & the fact that & Later & Research & essentially & perhaps & Usually \\
\hline that is to say & Finds & Thought & Page X & Said & Estimated & plausibly & Unlikely \\
\hline that is & Find & Thinks & $\mathrm{X}$ above & Says & Feel & Possibly & wouldn’t \\
\hline this means & I believe & Think & Table & Show & Fairly & Possible & Would \\
\hline which means & Found & Undeniable & $\mathrm{X}$ before & Shows & Feels & Postulated & \\
\hline Viz & Incontestable & Truly & Earlier & Studies & $\begin{array}{l}\text { from this } \\
\text { perspective }\end{array}$ & Postulate & \\
\hline Boosters & in fact & Undeniably & $\mathrm{X}$ below & Suggest & Felt & Postulated & \\
\hline Always & Incontestably & Undoubtedly & Section & Suggests & from my & Presumably & \\
\hline Actually & Incontrovertibly & Undisputedly & Evidentiality & Hedges & Perspective & Presumable & \\
\hline Apparent & Incontrovertible & well known & according to & Almost & $\begin{array}{l}\text { from our } \\
\text { perspective }\end{array}$ & Probably & \\
\hline Believed & Indisputable & won’t & (to) cite $X$ & About & Frequently & Probable & \\
\hline Believes & Indeed & $\begin{array}{l}\text { without } \\
\text { doubt }\end{array}$ & (date)/(name) & Apparent & Generally & Quite & \\
\hline Beyond & it is clear & TRUE & (to) quote X & Apparently & Guess & Relatively & \\
\hline Believe & Indisputably & Endophoric & according to $\mathrm{X}$ & Appear & in most cases & rather $\mathrm{x}$ & \\
\hline $\begin{array}{l}\text { beyond } \\
\text { doubt }\end{array}$ & it is known that & See & [ref. no.]/[name] & appear to be & in general & Roughly & \\
\hline Certain & Know & (In) Part X & Argue & Appeared & in my opinion & Should & \\
\hline by far & Known & $\begin{array}{l}\text { (In) Chapter } \\
X\end{array}$ & Argues & Appears & $\begin{array}{l}\text { in most } \\
\text { instances }\end{array}$ & Seems & \\
\hline
\end{tabular}


Table 6. Proposed metadiscoursal features: interactional category

\begin{tabular}{|c|c|c|c|c|c|c|c|c|c|}
\hline $\begin{array}{l}\text { Attitude } \\
\text { Markers }\end{array}$ & Fortunate & $\begin{array}{l}\text { Understa } \\
\text { ndable }\end{array}$ & intend to & to repeat & Last & Digress & do not & Order & $\begin{array}{l}\text { Self-ment } \\
\text { ions }\end{array}$ \\
\hline$!$ & Fortunately & $\begin{array}{l}\text { Understa } \\
\text { ndably }\end{array}$ & Intention & to sum up & Lastly & Resume & employ & one's & We \\
\hline Admittedly & have to & $\begin{array}{l}\text { Unexpect } \\
\text { ed }\end{array}$ & my goal is & $\begin{array}{l}\text { to } \\
\text { summarize }\end{array}$ & leads to & Revisit & Ensure & Our & Our \\
\hline Agree & Hopeful & $\begin{array}{l}\text { Unexpect } \\
\text { edly }\end{array}$ & my purpose & $\begin{array}{l}\text { Sequencin } \\
\mathrm{g}\end{array}$ & $\begin{array}{l}\text { listing ( } \mathrm{a}, \mathrm{b}, \mathrm{c} \text {, } \\
\text { etc.) }\end{array}$ & So & estimate & ought & Us \\
\hline Agrees & Hopefully & $\begin{array}{l}\text { Unfortun } \\
\text { ate }\end{array}$ & Objective & $\begin{array}{l}\text { to start } \\
\text { with }\end{array}$ & Nevertheless & shift to & evaluate & picture & My \\
\hline Amazed & Important & $\begin{array}{l}\text { Unfortun } \\
\text { ately }\end{array}$ & Purpose & $\begin{array}{l}\text { (in) the } \mathrm{X} \\
\text { part }\end{array}$ & Nonetheless & turn to & Find & Pay & I \\
\hline Amazing & Importantly & Unusual & seek to & $\begin{array}{l}\text { (in) chapter } \\
\mathrm{X}\end{array}$ & Next & $\begin{array}{l}\text { to look } \\
\text { more } \\
\text { closely }\end{array}$ & Follow & Prepare & $\begin{array}{l}\text { the } \\
\text { author's }\end{array}$ \\
\hline Amazingly & Inappropriate & $\begin{array}{l}\text { Unusuall } \\
\mathrm{y}\end{array}$ & want to & $\begin{array}{l}\text { (in) the } X \\
\text { chapter }\end{array}$ & $\begin{array}{l}\text { Numbering } \\
(1,2,3 \text {, etc. })\end{array}$ & Well & Go & remember & the author \\
\hline $\begin{array}{l}\text { Appropriat } \\
\mathrm{e}\end{array}$ & $\begin{array}{l}\text { Inappropriatel } \\
\mathrm{y}\end{array}$ & Usual & $\begin{array}{l}\text { we will } \\
\text { emphasise }\end{array}$ & $\begin{array}{l}\text { (in) section } \\
X\end{array}$ & $\begin{array}{l}\text { on the } \\
\text { contrary }\end{array}$ & $\begin{array}{l}\text { Engagem } \\
\text { ent } \\
\text { Markers }\end{array}$ & have to & recall & the writer \\
\hline $\begin{array}{l}\text { Appropriat } \\
\text { ely }\end{array}$ & Interest & $\begin{array}{l}\text { Announc } \\
\text { e Goals }\end{array}$ & $\begin{array}{l}\text { we will } \\
\text { focus on }\end{array}$ & $\begin{array}{l}\text { (in) this } \\
\text { section }\end{array}$ & $\begin{array}{l}\text { on the other } \\
\text { hand }\end{array}$ & $\begin{array}{l}\text { (the) } \\
\text { reader's }\end{array}$ & imagine & Review & $\begin{array}{l}\text { the } \\
\text { writer's }\end{array}$ \\
\hline Astonished & Interesting & $\begin{array}{l}\text { (in) this } \\
\text { chapter }\end{array}$ & wish to & $\begin{array}{l}\text { (in) the X } \\
\text { section }\end{array}$ & Or & About & $\begin{array}{l}\text { incident } \\
\text { ally }\end{array}$ & Regard & Mine \\
\hline $\begin{array}{l}\text { Astonishin } \\
\mathrm{g}\end{array}$ & Interestingly & $\begin{array}{l}\text { (in) this } \\
\text { part }\end{array}$ & $\begin{array}{l}\text { would like } \\
\text { to }\end{array}$ & $\begin{array}{l}\text { (in) this } \\
\text { chapter }\end{array}$ & Secondly & Add & increase & Recover & $\mathrm{Me}$ \\
\hline $\begin{array}{l}\text { Astonishin } \\
\text { gly }\end{array}$ & Must & $\begin{array}{l}\text { (in) this } \\
\text { section }\end{array}$ & $\begin{array}{l}\text { Label } \\
\text { stages }\end{array}$ & $\begin{array}{l}\text { (in) this } \\
\text { part }\end{array}$ & Second & Allow & Input & Remove & \\
\hline Correctly & Ought & Aim & all in all & (in) part X & Subsequently & Analyse & Insert & Refer & \\
\hline Curious & Pleased & desire to & at this point & $\begin{array}{l}\text { Accordingl } \\
\mathrm{y}\end{array}$ & Third & Apply & $\begin{array}{l}\text { integrat } \\
\mathrm{e}\end{array}$ & Select & \\
\hline Curiously & Prefer & Focus & at this stage & Also & Then & Arrange & Key & See & \\
\hline Desirable & Preferable & Goal & by far & Although & Thirdly & Assess & Let & Should & \\
\hline Desirably & Preferably & $\begin{array}{l}\text { here I do } \\
\text { this }\end{array}$ & $\begin{array}{l}\text { for the } \\
\text { moment in } \\
\text { brief }\end{array}$ & Besides & Though & Assume & let us & Set & \\
\hline Disagree & Preferred & $\begin{array}{l}\text { here I } \\
\text { will }\end{array}$ & $\begin{array}{l}\text { in } \\
\text { conclusion } \\
\text { in }\end{array}$ & $\begin{array}{l}\text { even } \\
\text { though }\end{array}$ & Three & $\begin{array}{l}\text { by the } \\
\text { way }\end{array}$ & let $x=y$ & Suppose & \\
\hline Disagreed & Remarkable & I argue & $\begin{array}{l}\text { conclusion } \\
\text { in short }\end{array}$ & Fifthly & Thus & Calculate & let's & State & \\
\hline Disagrees & Remarkably & I discuss & in sum & Fifty & Two & Choose & Let's & Show & \\
\hline $\begin{array}{l}\text { Disappoint } \\
\text { ed }\end{array}$ & Shocked & I intend & in summary & Finally & to begin & Classify & Lets & think of & \\
\hline $\begin{array}{l}\text { Disappoint } \\
\text { ing }\end{array}$ & Shocking & I propose & Now & First & Whereas & Compare & look at & turn us & \\
\hline $\begin{array}{l}\text { Disappoint } \\
\text { ingly }\end{array}$ & Shockingly & I seek & on the whole & first of all & While & Connect & Must & think & \\
\hline Dramatic & Striking & I suggest & $\begin{array}{l}\text { on the whole } \\
\text { overall }\end{array}$ & Firstly & Yet & Consider & Mount & $\begin{array}{l}\text { take (a } \\
\text { look/as } \\
\text { example) }\end{array}$ & \\
\hline $\begin{array}{l}\text { Dramatical } \\
\text { ly }\end{array}$ & Strikingly & $\begin{array}{l}\text { I will } \\
\text { emphasis } \\
\mathrm{e}\end{array}$ & Overall & Five & $\begin{array}{l}\text { Topic } \\
\text { Shifting }\end{array}$ & Consult & measure & Think & \\
\hline Essential & Surprised & $\begin{array}{l}\text { I will } \\
\text { focus on }\end{array}$ & so far & Four & back to & Contrast & Mark & Use & \\
\hline Essentially & Surprising & I wish & Summarise & Fourth & Now & Define & need to & We & \\
\hline Even & Surprisingly & $\begin{array}{l}\text { I would } \\
\text { like to }\end{array}$ & Summarize & Fourthly & move on & $\begin{array}{l}\text { Demonstr } \\
\text { ate }\end{array}$ & Note & Us & \\
\hline Expected & Unbelievable & $\begin{array}{l}\text { in this } \\
\text { chapter }\end{array}$ & thus far & Hence & in regard to & Determine & Notice & Your & \\
\hline Expectedly & Unbelievably & $\begin{array}{l}\text { in this } \\
\text { section }\end{array}$ & to conclude & However & return to & Develop & observe & You & \\
\hline
\end{tabular}




\section{Appendix B}

Table 7. Developed expressions of metadiscourse features

Expression for Code Glosses
Expression for Endophorics
Expression for Evidentials
Expression for Frame Markers:
Sequencing

for example|called|as a matter of fact| e.g.|defined as|I mean|for instance|in fact|i.e.|indeed| in other words|namely|known as|put another way|or|specifically|say|that is|such as|that means|that is to say|viz|this means|which means

see|In Part X|In Chapter X|In the X chapter|In Section X|In the X section|In the X part|In This part|In This chapter|chapter|In This section|discussed above/discussed before|discussed below|discussed earlier|discussed later|example|fig|Example X|Fig. X|Figure $\mathrm{X} \mid$ figure|P. $\mathrm{X}$ |noted|Page $\mathrm{X} \mid$ page|table|section $\mid \mathrm{X}$ above|Table $\mathrm{X} \mid \mathrm{X}$ below $\mid \mathrm{X}$ earlier|X before $\mid \mathrm{X}$ later

According to $\mid$ to cite $\mathrm{X} \mid($ date $) /($ name $)$ to quote $\mathrm{X} \mid$ according to $\mathrm{X} \mid[$ ref. no.]/[name]|argue|believe|argues|believes|cite|cited|cites|claim|claims|demonstrate|demonstrates|est ablished|found that|literature|point out|point tolpoints out|points to|prove|proves|quote|quoted|research|said|says|show|shows|studies|suggest|suggests to start with|in part $\mathrm{X} \mid$ in chapter $\mathrm{X} \mid$ in section $\mathrm{X} \mid$ in the $\mathrm{X}$ part|in the $\mathrm{X}$ chapter|in the $\mathrm{X}$ section|in the $\mathrm{X}$ chapter|in this chapter|in this part|in this section |accordingly|also|although|besides|even though|fifthly|fifty|finally|first|first of all|firstly|five|four|fourth|fourthly|hence|however|last|lastly|leads to|nevertheless|listing (a, b, c, etc.)|nonetheless|next|on the contrary|numbering $(1,2,3$, etc.)|on the other hand|second|or|subsequently|secondly|then|secondly|third|though|three|thus|to

begin|two|whereas|while|yet|thirdly

Expression for Frame Markers: Label Stages

at this point|all in all|by far|at this stage|in conclusion|for the moment in brief|in short|in conclusion|in summary|in sum|on the whole|now|on the whole overall|overall|summarise|so far|summarize|to conclude|thus far|to sum up|to repeat|to conclude|to summarize

desire to|in this part|in this chapter|aim|focus|here I do this|in this section|here I will|goal|I argue|I

Expression for Frame Markers: Announce Goals discuss|I intend|I propose|I seek|I suggest|I will emphasise|I will focus on|I wish|I would like to|in this chapter|in this section|intend to|intention|my goal is|my purpose|objective|seek to|purpose|we will emphasise|want to|we will focus on|wish to|would like to

Expression for Frame Markers: Shift Topic

digress|back to|move on|in regard to|resume|now|revisit|return to|so|shift to|turn to|to look more closely|well

still|accordingly|again|additionally|alternatively|also|and|although|as a consequence|at the same time|as a result|besides|because|by contrast|but|consequently|by the same token|equally|conversely|further|even though|furthermore|however|hence|in $\quad$ contrast|in

Expression for Transition Markers addition|leads to|in the same way|moreover|likewise|nonetheless|nevertheless|on the other hand|on the contrary|result in|rather|since|similarly|so as to|so|the result is|still|therefore|thereby|thus|though|while|whereas|yet

Expression for Self-Mentions me|I|my|mine|the author|our|the writer|the writer's|the author's|us|we

about|the reader's|allow|add|apply|analyse|assess|arrange|by the way|assume $\mid$ choose $\mid$ calculate $\mid$ classify|connect|compare|consult|contrast|consider|define $\mid$ determine $\mid \mathrm{d}$ emonstrate|develop|employ|do not|estimate| ensure|evaluate|follow|find|have to|go|incidentally|imagine|increase|input|insert|integrate|key|let|let $\mathrm{x}=\mathrm{y} \mid$ let us|lets|let's|mark|look at|mount|measure|needto|note|must|observe|notice|order|one's|our|ought|picture|pay|recall|recover|pr epare|regard|refer|remove|remember|see|review|set|select|show|should|suppose|state|take as example|take a look|think about|think|turn us|think of|use|us|we|your|you always|actually|believe|apparent|believes|believed|beyond foubt|beyond|by $\quad$ far|certain that|certain|certainly|clear|certainty|conclusively|clearly|definite|decidedly|demonstrate|definitely|de monstrated|determine|doubt|demonstrates|doubtless|establish|essential|even

if|evident|established|find|finds|evidently|I believe| found|in Expression for Emphatics fact|incontestably|incontestable|incontrovertibly|incontrovertible|indeed|indisputably|indisputable|it (Boosters): Certainty Markers is known that|it is clear|know|must|never|known|no doubt|known|obvious|of course|obviously|proved|proves|prove|realized|realize|realizes|should|show|really|shown|showed|sur e|shows|surely|shows|think| the fact that|thinks|undeniable|thought|truly|undisputedly|undeniably|undoubtedly|without doubt|well known|TRUE|won't

amazingly|admittedly|appropriately|agrees|agree|amazing|appropriate|amazed|astonishing|astonishi ng|astonished|correctly|curiously|disappointing|curious|disagree|Desirably|desirable|disappointed|di sagreed|disappointingly|disagrees|dramatically|dramatic|essential|even|even $\mathrm{x}$ |essentially|expected|fortunately|expectedly|fortunate|have

to|hopefully|important|hopeful|importantly|interest|inappropriate|inappropriately|interesting|prefer|i nterestingly|pleased|Preferable|preferably|preferred|must|ought|remarkable|remarkably|surprisingly| 
shocked|shocking|shockingly|striking|strikingly|surprised|surprising|unfortunate|unfortunately|unus ually|understandably|unbelievable|unbelievably|understandable|unexpected|unexpectedly|unusual|u sual

almost|about|apparent|apparently|appear|appear

be|appeared|approximately|appears|argued|argue|around|argues|assumed|assume|believed|certain amount|broadly|certain

extent|claim|certain

level|claimed|could|claims|couldn’t|doubtful|doubt|estimate|essentially|fairly|estimated|feels|feel|fre quently|felt|from my perspective|from this perspective|from our perspective|guess/in Expression for Hedges: general|generally|in most cases|in my opinion|in most instances|in our opinion|in my view|in Uncertainty Markers thisview| in our view|indicate|largely|indicated|likely|indicates|little|may|maybe|mainly| mostly|might|often|on the whole|not understood|perhaps|plausible|ought|plausibly|possibly|postulate|possible|postulated|presumable|post ulates|presumably|probably|probable|rather

$\mathrm{x}$ |quite|roughly|seems|relatively|should|somewhat|suggest|sometimes|suggests|suppose|suggested|su pposed|suspect|supposes|suspects|tended to|tend to|tends to|typical| to my knowledge|typically|uncertainly|uncertain|unclearly|unlikely|unclear|would|usually|wouldn’t

\section{Copyrights}

Copyright for this article is retained by the author(s), with first publication rights granted to the journal.

This is an open-access article distributed under the terms and conditions of the Creative Commons Attribution license (http://creativecommons.org/licenses/by/4.0/). 